\title{
Selection for high and low, colony weight gain in the honey bee, Apis mellifera, using selected queens and random males
}

\author{
NW Calderone a, b, MK Fondrk c
}

The Ohio State University, Department of Entomology, Columbus, OH 43210, USA

(Received 13 June 1990; accepted 24 October 1990)

\begin{abstract}
Summary - Seasonal colony weight gain (honey production) in the honey bee, Apis mellifera, can be modified by selection. Two-way selection for strains of honey bees exhibiting high or low seasonal colony weight gain was made for 3 generations. In each generation, daughter queens were reared from selected colonies and permitted to mate naturally with unselected males. Two strains of honey bees were produced that differed significantly with respect to seasonal colony weight gain. These results suggest that commercial and hobbyist beekeepers can increase the efficiency of honey production by using a simple selection and mating scheme. Several variables were also evaluated as indicators of seasonal colony weight gain. Short-term colony weight gain was significantly correlated with seasonal colony weight gain and is a useful aid to selection. Early-winter colony weight, latewinter colony weight, early-spring colony weight, and winter weight loss were not correlated with seasonal colony weight gain and do not appear to be useful aids to selection.
\end{abstract}

Apis mellifera / honey yield / colony-level selection

\section{INTRODUCTION}

The selection of improved strains of honey bees is a frequently discussed topic in the bee literature. However, despite demonstrations of genetic variability for a number of traits, benefits resulting from selection for those traits have not generally been realized by beekeepers. The paucity of commercially available selected strains of honey bees can be traced, in part, to several aspects of honey-bee biology. First, when a breeder employs colonylevel selection, the queen-worker caste system results in measurements being based partially on the aggregate performance of workers, rather than directly on

\footnotetext{
a Correspondence and reprints.

b Current address : USDA-ARS, Bee Research Laboratory, Building 476 BARC-EAST, Beltsville, MD 20705, USA

c Current address : Department of Entomology, University of California, Davis, CA 95616, USA
} 
the performance of the reproductive individuals. Second, multiple mating (polyandry) by queens lowers the degree of genetic relatedness among the workers being evaluated and makes control over the male gametic contributions to succeeding generations difficult. These factors reduce the response to selection. Additionally, the honey-bee's sex-determining mechanism results in a high proportion of inviable brood and a corresponding reduction in colony viability when the effective size of the breeding population is restricted, as is common with many mating systems. These impediments can be overcome, in part, through the use of isolated mating yards, instrumental insemination, and controlled breeding populations. However, these remedies require considerable skill and effort on the part of the breeder and have not, in general, been implemented by the various sectors of the beekeeping industry in the United States.

An ideal system for hobbyists, commercial queen producers, and commercial honey producers is one that incorporates a modest selection coefficient, produces naturally-mated queens, and avoids the difficulties associated with instrumental insemination, isolated mating yards, and the maintenance of controlled breeding populations. Rothenbuhler (1980) suggested that beekeepers might avoid these difficulties and still make improvements in their stock by carefully evaluating their colonies, rearing daughter queens from the 'best' $10 \%$ of those colonies, and allowing those daughters to mate naturally with males from other than the queen mothers. We evaluated this technique as a tool for increasing honey production using seasonal colony weight gain as an indicator of honey production (McLellan, 1977). We also evaluated short-term colony weight gain, early-winter colony weight, early-spring colony weight, and winter weight loss as indicators of seasonal colony weight gain.

\section{MATERIALS AND METHODS}

Two-way selection for high and low, seasonal colony weight gain was conducted at The Ohio State University Bee Laboratory from 1983 through 1986. Seasonal colony weight gain is defined here as the net change in colony weight from the first nectar flow in the spring through the end of the yellow sweetclover (Melilotus officinalis) nectar flow in early summer. This period generally includes the major nectar flow in the central Ohio area. In 1986, this period was extended through the soybean nectar flow (Glycine max var) which ended in early August.

\section{Colony management}

Colonies were kept in a common apiary. Each was maintained in a 10-frame, standard depth, Langstroth-style hive consisting of 2 brood chambers separated from the honey-storage area by a queen excluder. Combs for honey storage were provided to all colonies at the same time whenever the average colony weight indicated that there were $<10$ combs available for additional storage. Colonies were inspected at 10-d intervals in the spring, at which time brood chambers were reversed, queen cells removed, and disease inspections performed. Colonies with $>50$ cells of chalkbrood (Ascophaera apis) were removed from the experiment. No cases of American or European foulbrood were observed. No attempt was made to equalize colony populations at this time (Szabo and Lefkovitch, 1987) because variation in the size of colony populations may account for a significant proportion of variation in honey production (Farrar, 1937; Cale and Gowen, 1956; Moeller, 1961) and may be heritable. All colonies were inspected in November to ensure that at least $29,25 \mathrm{~kg}$ of honey were available for overwintering.

\section{Selection criterion and mating system}

A base population of 33 colonies with naturallymated queens obtained from several commercial sources was evaluated for variability in seasonal colony weight gain during the spring and 
early summer of 1983 . Colonies were weighed every $8 \mathrm{~d}$ (short-term weight gains) during May and June until the end of the sweetclover nectar flow. Selections were made on the basis of total weight gain during that period. Queens from the 3 colonies with the highest seasonal weight gains were selected to initiate 3 sublines comprising the high strain. Queens from the 3 colonies with the lowest gains were selected to initiate 3 sublines comprising the low strain.

Daughter queens were reared from the queen mother of each subline, marked for identification, introduced to queen-mating colonies, and permitted to mate naturally. Reproductive isolation of the daughter queens from the parent population was achieved by maintaining the queen-mating apiary $>23 \mathrm{~km}$ from the parent apiary (Peer, 1957). Consequently, all daughter queens had access to the same pool of unselected males. Mated queens were introduced to colonies from the preceding generation during the first $10 \mathrm{~d}$ of August. Assignment to colonies was randomized. Requeening in early August ensured complete replacement of the worker populations by the time colonies entered winter. Colonies were evaluated the following season, and the queen from each subline heading the colony with the highest (high-strain sublines) or lowest (low-strain sublines) seasonal weight gain was selected to continue that subline in subsequent generations. The same selection, mating, and requeening procedures were followed each year.

In 1984 and 1985, colony weights were obtained in December or January, and in late March (static weights). These were followed by bi-weekly weighings (short-term weight gains) during the evaluation period that extended from early May to late June (1984) or early July (1985), depending on the termination date of the nectar flow. In 1986, colonies were weighed at 30-d intervals (short-term weight gains) and the evaluation period was continued through early August due to a dearth of nectar in May and June.

\section{Statistical model}

Variation in seasonal colony weight gain was analyzed using a nested analysis of variance (Kempthorne, 1952; Sokal and Rohlf, 1981) model with strain (high or low) as the main effect and subline as the nested effect (the composition of the expected mean squares is given in table I) :

$$
y_{i j k}=\mu+a_{i}+b_{i j}+\varepsilon_{i j k}
$$

$y_{i j k}=$ seasonal weight gain of the $k$ th colony of the $j$ th subline of the $i$ th strain; $\mu=$ average seasonal weight gain of all colonies; $a_{i}=$ average deviation of colonies of the ith strain from $\mu$; $b_{i j}=$ average deviation of colonies of the jth subline nested within the ith strain from the average seasonal weight gain of colonies of the ith strains; $\varepsilon_{i j k}=$ individual error.

A 1-tailed test of significance was used to test the hypothesis that the average weight gain by colonies from the high strain was less than or equal to the average weight gain by colonies from the low strain $\left(\left(H_{0} \mu_{H}<=\mu_{L} ; H_{A}: \mu_{H}>\mu_{L}\right)\right.$. The mean square $s^{2}{ }_{b}$ is the appropriate error term to test for strain effects assuming that subline effects are significant (table 1). Subline effects were evaluated using the mean square $s^{2}$ as the error term using a 2-tailed test of significance. The mean square $s^{2}$ is also the appropriate error term for testing strain effects if subline effects are not significant (table l). We report the results of 1-tailed tests for strain effects using both $s^{2}{ }_{b}$ and $s^{2}$ as error terms.

Table I. Composition of expected means squares used in nested analysis of variance of seasonal colony weight gain.

$$
\text { Source of variation } \quad d f \quad \text { Mean square } \quad E(M S)
$$

$\begin{array}{lrll}\text { Between strains }\left(a_{i}\right) & (I-1) & s^{2}{ }_{a} & s^{2}+k s^{2}{ }_{b}+k j s^{2}{ }_{a} \\ \text { Among sublines within strains }\left(b_{i j}\right) & \mathrm{I}(\mathrm{J}-1) & s^{2}{ }^{a} & s^{2}+k s^{2}{ }_{b} \\ \text { Colony within subline }\left(\varepsilon_{i j k}\right) & \mathrm{JJ}(\mathrm{K}-1) & s^{2} & s^{2} \\ \text { Total } & \mathrm{IJK}-1 & & \end{array}$




\section{Evaluation of indicators of seasonal colony weight gain}

The ability to make effective selections for honey production early in the season is important because it permits the production of the next generation of colonies within the same year, thereby increasing the rate of stock improvement. Short-term colony weight gain is one possible indicator of seasonal colony weight gain. Correlation coefficients between seasonal colony weight gain and weekly (1983), bi-weekly (1984, 1985), and monthly (1986) short-term weight gains were calculated. Early-winter colony weight, early-spring colony weight, and winter weight loss (principally honey consumption) were also evaluated as indicators of seasonal colony weight gain. Correlation coefficients were calculated separately for the high and low strains in 1984, 1985, and 1986.

\section{RESULTS}

The distribution of seasonal weight gains for the base population of 33 unselected colonies is shown in figure 1 . The 3 black boxes and the 3 stripped boxes give the seasonal weight gains for the colonies used to establish the 3 low-strain and 3 high-strain sublines, respectively. Season-

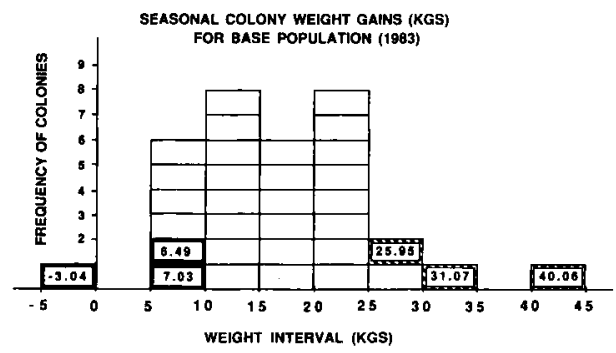

Fig 1. Frequency distribution for seasonal colony weight gain for the base population of $33 \mathrm{col}-$ onies in 1983. Black boxes represent colonies selected to establish the 3 low-strain sublines. Stripped boxes represent colonies selected to establish the 3 high-strain sublines. The average seasonal colony weight gain for these 2 groups was 3.49 and $32.36 \mathrm{~kg}$, respectively. al colony weight gain by colonies of the high strain was significantly greater than weight gain by colonies of the low strain after the second and third selected generations (fig 2). The difference in seasonal colony weight gain between the high and low strains expressed as a proportion of the average gain based on colonies from both strains was 0.07 in 1984, 0.25 in 1985, and 1.06 in 1986. These results demonstrate a genetic component to variability in seasonal colony weight gain and suggest that continuous progress was being made.

\section{Analysis of selection}

The average gains for the base population and for the 2 selected strains are presented as deviations from their respective annual averages based on all colonies (fig 2). The average seasonal colony weight gain in 1983 was $16.96 \mathrm{~kg} \pm 1.42 \mathrm{~kg} \mathrm{SE}(n=$ 33). The average gain in 1984, the first selected generation, was $75.99 \mathrm{~kg} \pm 3.68 \mathrm{~kg}$ $\mathrm{SE}(n=12)$ for colonies from the low strain and $81.59 \mathrm{~kg} \pm 4.11 \mathrm{~kg}$ SE $(n=13)$ for colonies from the high strain $(F=0.21(1,4$ df), $P>0.50$ using the mean square for

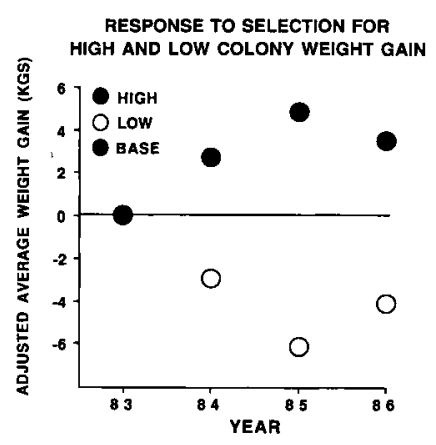

Fig 2. Results of selection for high and low colony weight gain. Each average is presented as a deviation from the average gain for that year based on all colonies. 
subline, $s^{2} b$, as the error term; and $F=$ $0.34(1,19 \mathrm{df}), P>0.50$ using the mean square $s^{2}$ as the error term). Subline effects were not significant $(F=1.60(4,19$ df), $P>0.25)$. The average gain in 1985 , the second selected generation, was 44.79 $\mathrm{kg} \pm 3.20 \mathrm{~kg} \mathrm{SE}(n=18)$ for colonies from the low strain and $55.75 \mathrm{~kg} \pm 2.24 \mathrm{~kg} \mathrm{SE}(n$ $=23$ ) for colonies from the high strain ( $F=$ 9.46 (1, $2 \mathrm{df}$ ), $P<0.05$ using the mean square for subline, $s^{2} b$, as the error term; and $F=9.49$ (1, $37 \mathrm{df}), P<0.005$ using the mean square error $s^{2}$ as the error term). Subline effects were not significant $(F=1.00(2,37 \mathrm{df}), P>0.20)$. The average gain in 1986, the third selected generation, was $3.01 \mathrm{~kg} \pm 1.11 \mathrm{~kg} \mathrm{SE}(n=16)$ for colonies from the low strain and $10.64 \mathrm{~kg} \pm$ $1.96 \mathrm{~kg} \mathrm{SE}(n=19)$ for colonies from the high strain $(F=6.05$ ( $1,3 \mathrm{df}), P<0.05$ using the mean square for subline, $s^{2} b$, as the error term; and $F=11.33(1,30 \mathrm{df}), P$ $<0.005$ using the mean square $s^{2}$ as the error term). Subline effects were not significant $(F=1.87(3,30 \mathrm{df}), P>0.15)$. The difference between the 2 selected strains was greatest in 1985 (difference between strains $=10.96 \mathrm{~kg}$ : average gain based on both strains $=50.94 \mathrm{~kg}$ ). However, the difference between the 2 strains expressed as a proportion of the average gain for a year based on both strains was greatest in 1986 (difference between strains $=7.63 \mathrm{~kg}$ average gain based on both strains $=7.15$ $\mathrm{kg})$.

The coefficient of variation of seasonal colony weight gain was greatest when the average gain was low, and declined rapidly as the average gain increased. The coefficients of variation for the base population (1983) was 48.2 . The coefficients of variation for the high and low strains, respectively, were 18.2 and 16.8 in 1984, 19.2 and 30.3 in 1985, and 80.3 and 147.9 in 1986. The relationship between the coefficient of variation and the average seasonal colony weight gain is described by the function $Y=339.63 X-0.68$ (fig 3). Variation in average seasonal colony weight gain accounted for $98 \%$ of the variation in the coefficient of variation.

\section{Correlation analyses}

Results of the correlation analysis of shortterm colony weight gain with seasonal colony weight gain are reported in table $\mid i-V$

Table II. Correlations between 8-d colony weight gain (Gain 1 - Gain 6) or initial weight $(05 / 10 / 1983)$ with seasonal colony weight gain $(05 / 10 / 1983-06 / 27 / 1983)$ for the base population in 1983.

\begin{tabular}{llll}
\hline Weight & $r$ & $p$ & $n$ \\
\hline & & & \\
Gain 1 & 0.82 & 0.0001 & 33 \\
Gain 2 & 0.60 & 0.0002 & 33 \\
Gain 3 & 0.49 & 0.0042 & 33 \\
Gain 4 & 0.25 & 0.1610 & 33 \\
Gain 5 & 0.69 & 0.0001 & 33 \\
Gain 6 & 0.60 & 0.0003 & 33 \\
05/10/1983 & -0.18 & $>0.30$ & 33 \\
\hline
\end{tabular}

$r=$ Pearson correlation coefficient; $P=$ probability $>|r|$; $n=$ sample size.

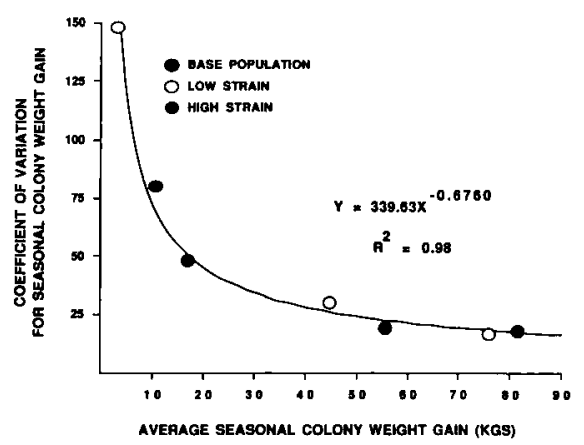

Fig 3. Relationship between the coefficient of variation for seasonal colony weight gain and the average seasonal colony weight gain. 
Table III. Correlations of 2-wk colony weight gain (Gain 1-Gain 4), early-winter colony weight (a: 12/07/1983), late-winter colony weight (b: 03/14/1984), early-spring colony weight (c: 05/01/1984), winter consumption (a-b), and winter consumption (a-c), with seasonal colony weight gain $(05 / 01 / 1984-06 / 27 / 1984)$ for the high and low strains.

\begin{tabular}{lcccrrrr}
\hline \multicolumn{1}{c}{ Weight } & \multicolumn{3}{c}{ High strain } & & \multicolumn{3}{c}{ Low strain } \\
& $r$ & $p$ & $n$ & $r$ & $p$ & $n$ \\
\hline & & & & & & \\
Gain 1 & 0.70 & 0.0080 & 13 & 0.85 & 0.0005 & 12 \\
Gain 2 & 0.59 & 0.0346 & 13 & 0.83 & 0.0008 & 12 \\
Gain 3 & 0.66 & 0.0139 & 13 & 0.68 & 0.0142 & 12 \\
Gain 4 & 0.73 & 0.0046 & 13 & 0.35 & 0.2689 & 12 \\
a: 12/07/1983 & 0.22 & 0.5396 & 10 & -0.51 & 0.1938 & 12 \\
b: 03/14/1984 & 0.30 & 0.4031 & 10 & -0.76 & 0.0259 & 8 \\
c: 05/01/1984 & 0.07 & 0.8097 & 13 & 0.50 & 0.0930 & 12 \\
a-c & 0.09 & 0.7972 & 10 & 0.27 & 0.5120 & 8 \\
a-b & 0.52 & 0.1238 & 10 & -0.55 & 0.1588 & 8 \\
& & & & & & & \\
\hline
\end{tabular}

$r=$ Pearson correlation coefficient; $P=$ probability $>|r| ; n=$ sample size.

(consecutive short-term gains are designated Gain 1, Gain 2, ... Gain n). Overall, 26 of 30 short-term colony gains were significantly correlated with seasonal colony weight gain. The average correlation of 8d weight gain with seasonal weight gain
(1983 data) was $0.57 \pm 0.08 \mathrm{SE}(n=6)$. The average correlation of 2-wk weight gain with seasonal weight gain (based on data from both high and low strains, and 1984 and 1985 pooled) was $r=0.69 \pm$ 0.032 SE $(n=18)$. The average correlation

Table IV. Correlations of 2-wk colony weight gain (Gain 1-Gain 5), early-winter colony weight (a: $01 / 03 / 1985$ ), early-spring colony weight (b: 03/29/1985), and winter consumption (a-b), with seasonal colony weight gain (03/29/1985-07/01/1985) for the high and low strains in 1985.

\begin{tabular}{lcccccc}
\hline \multicolumn{1}{c}{ Weight } & \multicolumn{3}{c}{ High strain } & & \multicolumn{3}{c}{ Low strain } \\
& $r$ & $p$ & $n$ & $r$ & $p$ & $n$ \\
\hline & & & & & & \\
Gain 1 & 0.77 & 0.0001 & 23 & 0.80 & 0.0001 & 18 \\
Gain 2 & 0.75 & 0.0001 & 23 & 0.67 & 0.0025 & 18 \\
Gain 3 & 0.77 & 0.0001 & 23 & 0.87 & 0.0001 & 18 \\
Gain 4 & 0.43 & 0.0387 & 23 & 0.69 & 0.0015 & 18 \\
Gain 5 & 0.57 & 0.0043 & 23 & 0.67 & 0.0024 & 18 \\
a: 01/03/1985 & 0.40 & 0.0610 & 23 & 0.06 & 0.8123 & 18 \\
b: 03/29/1985 & 0.48 & 0.0205 & 23 & -0.12 & 0.6423 & 18 \\
a-b & -0.22 & 0.3169 & 23 & 0.40 & 0.0959 & 18 \\
& & & & & & \\
\hline
\end{tabular}

$r=$ Pearson correlation coefficient; $P=$ probability $>|r| ; n=$ sample size. 
Table V. Correlations of $30-d$ colony weight gain (Gain 1-Gain 3) with seasonal colony weight gain (05/05/1986-08/08/1986) for the high and low strains in 1986.

\begin{tabular}{|c|c|c|c|c|c|c|}
\hline \multirow[t]{2}{*}{ Weight } & \multicolumn{3}{|c|}{ High strain } & \multicolumn{3}{|c|}{ Low strain } \\
\hline & $r$ & $p$ & $n$ & $r$ & $p$ & $n$ \\
\hline
\end{tabular}

$\begin{array}{llllrll}\text { Gain 1 } & 0.69 & 0.0011 & 19 & 0.41 & 0.1106 & 16 \\ \text { Gain 2 } & 0.65 & 0.0027 & 19 & -0.21 & 0.4288 & 16 \\ \text { Gain 3 } & 0.78 & 0.0001 & 19 & 0.57 & 0.0199 & 16\end{array}$

$r=$ Pearson correlation coefficient; $P=$ probability $>|r|$; $n=$ sample size.

of a 1-month weight gain with seasonal weight gain (1986 data) was $0.48 \pm 0.147$ SE $(n=6)$.

Results of the correlation analyses of early-winter colony weight, early-spring colony weight, and winter weight loss (winter honey consumption) with seasonal colony weight gain are reported in tables $11-V$ (static weights are indicated by the date on which they were obtained). Correlation of winter weight loss with seasonal colony weight gain was not significant. Correlation of early-winter and early-spring colony weight with seasonal colony weight gain was significant for 2 of 11 cases.

\section{DISCUSSION}

Selection for high and low colony weight gain using selected mothers and unselected random drones was moderately successful. Colonies from the high strain gained more than 3.5 times as much weight as colonies from the low strain after 3 generations of selection. However, the breeding program used to produce the high and low strains has several limita- tions. Variability in traits of economic importance (such pollinating ability, honey production, and defensive behavior) may reflect variability in both queen and worker phenotypes (colony level phenotype; Owen, 1989). To the degree that these traits are determined by worker phenotypes, selection is based on the aggregate performance of a large group of workers rather than directly on the phenotypes of the reproductive individuals. The expected response to selection may be less than that associated with individual selection (Lush, 1947a, b).

Polyandry amplifies the effects of the caste structure. Queens mate with 7-17 males (Page, 1986) prior to commencing egg-laying. Polyandry affects the selection process in 3 ways if these males are not under the control of the breeder. First, selection with polyandry is less efficient than selection with monandry because the pedigree coefficient of relatedness, $G_{x y}$ (Crozier, 1970; Pamilo and Corzier, 1982), among the workers being evaluated is reduced as the number of matings increases $\left(G_{x y}=0.75\right.$ with 1 mating, 0.50 with 2 matings, 0.32 with 7 matings, 0.28 with 17 matings). Second, queens reared from selected colonies to produce the next generation of workers are not necessarily representative of the better performing sib-ships in those colonies. Third, queens reared from selected colonies to produce the next generation of workers mate with an undetermined number of unselected males. Consequently, the paternity of their worker progeny, which form the basis for subsequent colony evaluations, is uncontrolled.

The joint costs of caste, polyandry, and uncontrolled paternity on the selection process may be measured through their effect on the degree of genetic relatedness between successive generations of evaluated individuals (fig 4). With individual selection, the parent-offspring relation is of interest. 


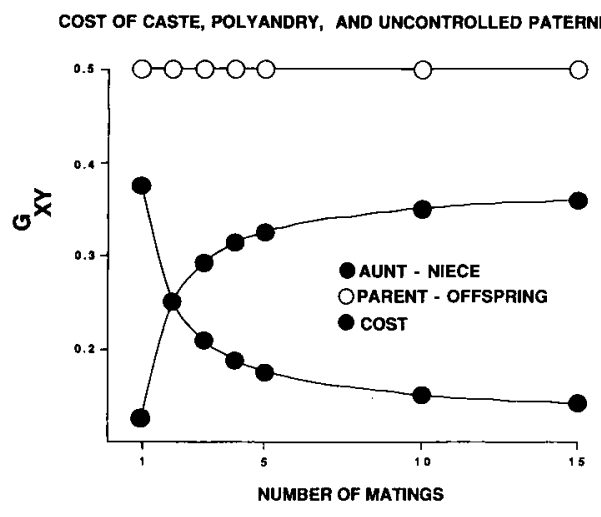

Fig 4. The joint costs of caste, polyandry, and uncontrolled paternity on $G_{x y}$ are represented by the shaded circles. These costs are measured as the difference in the pedigree coefficients of relatedness, $G_{x y}$, for the parent-offspring relationship (clear circles $-G_{x y}=0.50$ regardless of the number of uncontrolled matings) and the aunt-niece relationship (black circles).

$G_{x y}$ for parent-offspring is 0.50 regardless of the number of matings. With a caste structure, the relation of interest is that between 2 successive generations of workers (aunt-niece) $G_{x y}$ for these groups is at a maximum of 0.375 with monandry. It declines to a limiting value of 0.125 as the number of matings increases (for the aunt-niece relationship $G_{x y}=(1 / n)(0.375)$ $+(n-1) / n)(0.125))$, where $n$ is the number of matings; equal contributions from contributing males are assumed). Consequently, the caste structure has a minimum cost in terms of $G_{x y}$ of 0.125 with monandry $(0.50-0.375=0.125)$. This cost increases to a maximum of 0.375 (0.50$0.125=0.375$ ) as the number of matings increases.

The honey-bee's single-locus sexdetermining mechanism (Mackensen, $1951,1955)$ poses another complication for the breeder. Homozygosity at this locus is effectively lethal. Selection programs within small, closed populations (using either instrumental insemination or isolated mating yards) suffer from a loss in brood viability as the proportion of homozygotes at this major sex-determining locus increases. Woyke (1980) showed that brood viability in the progeny of multiply-mated queens should approach or exceed $75 \%$ to ensure maximum honey production. Page and Laidlaw (1982) determined the rate at which heterozygosity is lost in random mating, closed populations with different numbers of colonies. Allowing virgin queens to mate with drones from a large, unselected population minimizes the occurrence of homozygosity at the sex locus.

\section{Correlation analysis}

The correlation analysis of late-fall or early-winter colony weight, early-spring colony weight, and winter weight loss with seasonal colony weight gain indicate that these variables are not reliable indicators of honey production. Late fall (1984) and early winter (1985) colony weight were not significantly correlated with colony weight gain during the follwing season. Late winter (1984) or early spring (1985) colony weight were significantly correlated with the following seasonal colony weight gain in only 2 of 11 cases. These cases are not likely to be important because one correlation was positive while the other was highly negative. In none of the 6 cases examined was a significant correlation found between winter weight loss and colony weight gain during the following season. The non-significant correlations reported here could be the result of the small sample size $(8<n<33)$. Szabo and Lefkovitch (1988) reported a significant correlation between fall colony weight and honey produced the following season $(r=0.195, P<$ $0.01, n=187$ ). However, even with 187 
colonies, the correlation of fall colony weight with honey production was weak. Fall colony weight is probably most significant as a determinant of honey production when it is inadequate to sustain the buildup of a colony's population the following spring.

The correlation analysis of short-term colony weight gain with seasonal colony weight gain revealed that this variable is a moderately useful indicator of seasonal colony weight gain and confirms previous findings by Szabo (1982) and Oldroyd et al (1985). However, data from each of these studies suggest that there is considerable variability in this relationship. In the present study, the average correlation coefficients were 0.57 (1983), 0.69 (1984 and 1985), and 0.48 (1986); Szabo's (1982) correlation coefficients for $24-h$ gain with seasonal gain ranged from -0.17 to 0.94 (from 0.32 to 0.94 without the single negative coefficient). The correlations calculated by Oldroyd et al (1985) for 1-wk colony weight gain with seasonal colony weight gain ranged from $0.68-0.81$.

The moderate correlation of short-term colony weight gain with seasonal colony weight gain, the frequent occurrence of low and non-significant correlations, and the occasional negative correlation, suggest that the identification of additional predictive variables would considerably enhance the effectiveness of selection. Several other variables are correlated with seasonal colony weight gain or honey production. These include colony population (Farrar, 1937; Szabo, 1982; Szabo and Lefkovitch, 1989), 24-h pollen collection (Szabo, 1982), area of sealed brood (Soller and Bar-Cohen, 1967; Szabo, 1982; Szabo and Lefkovitch, 1989), weight of bees in colony (Szabo, 1982), daily flight activity (Szabo, 1980), queen weight (Nelson and Gary, 1983), and several morphological characteristics (Milne, 1980, 1985; Milne and Pries, 1984; Szabo and Lefkovitch, 1988). Szabo (1982) reported multiple correlation coefficients ranging from 0.90 0.98 for 3 variables related to honey production ( $24 \mathrm{~h}$ pollen collection, $24 \mathrm{~h}$ weight gain, and area of capped brood). Szabo's model should be evaluated further for its predictive value and applicability in different environments.

\section{Analysis of the coefficient of variation}

The coefficient of variation for seasonal colony weight gain was high when the average gain was low, but declined rapidly as the average gain increased. When the average gain is small, changes in colony weight are likely to be as indicative of changes in the amount of stored pollen, brood, and adult population as they are of changes in stored honey. Even if stored honey is important, variability in colony weight gain may still reflect stochastic events as well as genetic differences among colonies. For example, variability in foraging success in a resource limited environment could result in genetically similar colonies having large differences in phenotypes. Consequently, when the average gain is low, the large variance among colonies may be primarily the result of environmental effects and changes in hive components other than stored honey. Heritability will be low and the response to selection will be small.

We demonstrated successful selection under the most difficult of circumstances: no control over male parentage. Without selection of the contributing male gametes, both the rate and amount of progress that can be achieved is reduced. Complete control of parental contributions can be accomplished through the use of instrumental insemination (Laidlaw, 1987a, b) or isolated mating yards (Ruttner, 1988; Waller 
et al, 1989). Szabo and Lefkovitch (1987) reported successful selection for increased honey production using isolated mating yards. However, these techniques have not been assimilated into the routines of most commercial operations in the United States. Recently, Hellmich and Waller (1990) demonstrated that control over the male gametic contributions can be achieved with natural mating through the use of a drone saturation technique that eliminates the need to identify isolated mating stations. The technique evaluated in this study is readily available to any beekeeper requiring only a knowledge of queen rearing techniques and the ability to accurately weigh colonies.

\section{ACKNOWLEDGMENTS}

We thank RE Page, WC Rothenbuhler, H Shimanuki and SSY Young for helpful discussions concerning this project. We are grateful to $R$ Hellmich, G Hoffman, and two anonymous reviewers for commenting on the manuscript. We also thank The Ohio Agricultural Research and Development Center for constructing and donating the mechanical device required to weigh colonies. Additional support was provided by the Ohio State University James Hambleton Apicultural Memorial Award Fund.

\section{Résumé - Sélection d'abeilles (Apis mellifera $L$ ) ayant un facteur "gain de poids saisonnier de la colonie" fort ou faible, à l'aide de reines sélectionnées et de mâles pris au hasard. On a effec- tué sur 3 générations une sélection 2- voies pour obtenir des lignées d'abeilles, Apis mellifera, présentant un gain de poids saisonnier de la colonie (GPSC) fort ou faible. Trente trois colonies formant la po- pulation de base ont été pesées à inter- valles réguliers (gains de poids à court terme) du début du printemps jusqu'à la fin de la miellée principale. Les sélections ont}

été faites sur la base du gain total de poids durant cette période. Les reines des 3 colonies ayant le GPSC le plus élevé ont été choisies pour être à l'origine d'une souche élevée formée de 3 sous-lignées. Les reines des 3 colonies ayant le GPSC le plus faible ont été choisies pour être à l'origine d'une souche faible formée de 3 souslignées. Des reines filles ont été élevées à partir de ces colonies, et on les a laissées s'accoupler librement avec des mâles non sélectionnés dans un rucher isolé de la population mère. Les colonies obtenues ont été évaluées la saison suivante et la reine de chaque sous-lignée à la tête de la colonie ayant le GPSC le plus élevé (souslignées les plus élevées) ou le plus faible (sous-lignées les plus faibles) a été sélectionnée pour perpétuer cette sous-lignée dans les générations suivantes. Deux souches d'abeilles ont ainsi été produites, dont le GPSC différait significativement. Ces résultats suggèrent que les apiculteurs professionnels ou amateurs peuvent accroître l'efficacité de la production de miel grâce à un schéma simple de sélection et d'accouplement. Néanmoins les progrès possibles sont limités par le système d'accouplement utilisé dans ce programme de sélection. Ces limites sont une conséquence des effets de la caste, de la polyandrie et de la paternité non contrôlée. Plusieurs variables ont été évaluées en tant qu'indicateurs du PGSC. Le gain de poids de la colonie à court terme est significativement corrélé avec le PGSC et peut être un outil utile pour la sélection. Le gain de poids de la colonie au début de l'hiver, à la fin de l'hiver, au début de printemps et la perte de poids hivernale ne sont pas corrélés avec le PGSC et n'apparaissent donc pas comme des outils utiles pour la sélection.

Apis mellifera / sélection / rendement de miel 
Zusammenfassung - Selektion für hohe und niedrige Zunahmen des Volksgewichts durch Auswahl der Königinnen und freie Paarung. Eine Zweiweg-Selektion mit Bienenvölkern hoher oder niedriger Gewichtszunahme während der Saison wurde drei Generationen lang durchgeführt. Die Ausgangspopulation von 33 Völkern wurde vom zeitigen Frühjahr bis zum Ende der Haupttracht in regelmäßigen Abständen gewogen; auf diese Weise kamen wir zu den Kurzzeit-Zunahmen. Die Selektion wurde auf Grund der Gesamtzunahme während der Saison vorgenommen. Königinnen von den drei Völkern mit den höchsten Saisonzunahmen wurden zur Gründung von drei Unterlinien ausgewählt ("Hoch"-Stamm). Aus den drei Völkern mit den niedrigsten Gewichtszunahmen während der Saison wurden Königinnen für drei Unterlinien des "Niedrig"-Stammes gezogen. Die aus diesen ausgewählten Völkern aufgezogenen Jungköniginnen wurden auf isolierten Ständen frei gepaart. In der folgenden Saison wurden die nachgezogenen Königinnen geprüft und die Königinnen mit den jeweils höchsten, bzw niedrigsten Gewichtszunahmen des "Hoch"- oder "Niedrig"-Stammes für die Nachzucht zur Erhaltung des Stammes in der nachfolgenden Generation ausgewählt.

Auf diese Weise wurden zwei Bienenstämme erzeugt, die sich signifikant in der Gewichtszunahme während der Saison unterschieden. Diese Ergebnisse weisen darauf hin, da $B$ Erwerbs- und Freizeitimker den Honigertrag durch ein einfaches Selektions- und Paarungsschema steigern können. Das in diesem Selektionsprogramm benutzte Paarungsschema schränkt jedoch die erreichbare Geschwindigkeit wie das Gesamtausmaß des Fortschrittes ein. Diese Begrenzungen ergeben sich aus Einflüssen der Kaste, der Mehrfachpaarung sowie der unkontrollierten Wahl der Väter.
Darüber hinaus wurden mehrere Faktoren als Hinweise auf Gewichtszunahmen über die Saison geprüft. Die KurzzeitZunahmen waren signifikant mit der Gesamtzunahme während der Saison korreliert; sie sind deshalb nützliche Hilfen für die Selektion. Das Volksgewicht im Frühwinter, im Spätwinter, im zeitigen Frühjahr und der Gewichtsverlust während des Winters waren hingegen mit der Gewichtszunahme während der Trachtzeit nicht korreliert und sie ergeben deshalb keine brauchbaren Hinweise für die Selektion.

\section{Apis mellifera / Selektion / Honigertrag}

\section{REFERENCES}

Cale GH Jr, Gowen JW (1956) Heterosis in the honeybee (Apis mellifera L). Genetics 41, 292-303

Crozier RH (1970) Coefficients of relatedness and the identity of genes by descent in the Hymenoptera. Am Nat 104, 216-217

Farrar CL (1937) The influence of colony populations on honey production. J Agric Res 54, 945-954

Hellmich RL Jr II, Waller GD (1990) Preparing for Africanized honeybees: evaluating control in mating apiaries. Am Bee J 130, 537-542

Kempthorne O (1952) The Design and Analysis of Experiments. John Wiley and Sons, NY

Laidlaw HH (1987a) Instrumental insemination of honeybee queens: its origin and development. Bee World 68, 17-36

Laidlaw HH Jr (1987b) Instrumental insemination of honeybee queens: its origin and development . Bee World 68, 71-88

Lush JL (1947a) Family merit and individual selection as bases for selection. Part I. Am Nat 81, 241-261

Lush JL (1947b) Family merit and invidual selection as bases for selection. Part II. Am Nat $81,362-379$

Mackensen $O$ (1951) Viability and sex determination in the honey bee (Apis mellifera $\mathrm{L}$ ). Genetics 36, 500-509 
Mackensen O (1955) Further studies on a lethal series in the honey bee. $J$ Hered 46, 72-74

McLellan AR (1977) Honeybee colony weight gain as an index of honey production and nectar flow: a critical evaluation. $J$ App/ Ecol $14,401-408$

Milne CP Jr (1980) Laboratory measurement of honey production in the honeybee. III. Pupal weight of the worker. J Apic Res 19, 176-178

Milne CP Jr (1985) The need for using laboratory tests in breeding honeybees for improved honey production. J Apic Res 24, 237-242

Milne CP Jr, Pries KJ (1984) Honeybee corbicular size and honey production. J Apic Res 23, 11-14

Moeller FE (1961) The relationship between colony populations and honey production. USDA-ARS and WI Agric Exp Stat Prod Res Rep No 55

Nelson DL, Gary NE (1983) Honey productivity of honeybee colonies in relation to body weight, attractiveness and fecundity of the queen. J Apic Res 22, 209-213

Oldroyd BP, Moran C, Nicholas FW (1985) Diallel crosses of honeybees. I. A genetic analysis of honey production using a fixed effects model. J Apic Res 24, 243-249

Owen RE (1989) The effects of colony-level selection on social behavior. In: Genetic and Social Evolution (Breed MD, Page RE, eds) Westview Press, Boulder, CO

Page RE Jr (1986) Sperm utilization in social insects. Annu Rev Entomol 31, 297-320

Page RE Jr, Laidlaw HH Jr (1982) Closed population honeybees breeding. I. Population genetics of sex determination. $J$ Apic Res 21, 30-37

Pamilo P, Crozier RH (1982) Measuring genetic relatedness in natural populations: methodology. Theor Popul Biol 21, 171-193
Peer DF (1957) Further studies on the mating range of the honey bee, Apis mellifera L. Can Entomo/ 89, 108-110

Rothenbuhler WC (1980) Necessary links in the chain of honey bee stock improvement. $A m$ $B e J 120,223-225,304,305$

Ruttner F (1988) Breeding Techniques and Selection for Breeding of the Honeybee. The British Isles Bee Breeders Association, Munich

Sokal RR, Rohlf FJ (1981) Biometry. WH Freeman and Company NY, 2nd edn

Soller M, Bar-Cohen R (1967) Some observations on the heritability and genetic correlation between honey production and brood area in the honeybee. J Apic Res 6, 37-43

Szabo T (1980) Effect of weather factors on honeybee flight activity and colony weight gain. J Apic Res 19, 164-171

Szabo T (1982) Phenotypic correlations between colony traits in the honey bee. Am Bee $J 122,711-716$

Szabo T, Lefkovitch LP (1987) Fourth generation of close-population honeybee breeding. 1. Comparison of selected and control strains. $J$ Apic Res 26, 170-180

Szabo T, Lefkovitch LP (1988) Fourth generation of closed population honeybee breeding. II; Relationship between morphological and colony traits. Apidologie 19, 259-274

Szabo T, Lefkovitch LP (1989) Effect of brood production and population size on honey production on honeybee colonies in Alberta, Canada. Apidologie 20, 157-163

Waller GD, Hoopingarner RA, Martin JH, Loper JM, Fierro M Meliton (1989) Controlled natural matings of honey bee queens in southern Arizona. Am Bee J 129, 187-190

Woyke J (1980) Effect of sex allele homoheterozygosity on honeybee colony populations and on their honey production. I. Favourable development conditions and unrestricted queens. J Apic Res 19, 51-63 